\title{
We Are More Than Paperless People: Reflections on Creating Spaces, Narratives and Change with Undocumented Communities
}

\author{
Maria del Cielo Mendez ${ }^{1, *}$, Jennifer Ayala ${ }^{2, *}$ and Kimberly Rojas ${ }^{1}$ \\ 1 College of Arts and Sciences, Saint Peter's University, Jersey City, NJ 07306, USA; krojas19@saintpeters.edu \\ 2 School of Education, Saint Peter's University, Jersey City, NJ 07306, USA \\ * Correspondence: mardmendez18@saintpeters.edu (M.d.C.M.); jayala@saintpeters.edu (J.A.)
}

Citation: Mendez, M.d.C.; Ayala, J.; Rojas, K. We Are More Than

Paperless People: Reflections on

Creating Spaces, Narratives and

Change with Undocumented

Communities. Societies 2021, 11, 47.

https://doi.org/10.3390/soc11020047

Academic Editors: Krystal M. Perkins and Arita Balaram

Received: 1 February 2021

Accepted: 6 May 2021

Published: 14 May 2021

Publisher's Note: MDPI stays neutral with regard to jurisdictional claims in published maps and institutional affiliations.

Copyright: ( $\odot 2021$ by the authors Licensee MDPI, Basel, Switzerland. This article is an open access article distributed under the terms and conditions of the Creative Commons Attribution (CC BY) license (https:// creativecommons.org/licenses/by/ $4.0 /)$.

\begin{abstract}
In this piece, we share some insights gleaned from oral histories of immigrant organizers involved in New Jersey state campaigns for access to higher education, weaving them with scholarly personal narratives (Nash \& Viray, 2013) from the authors on their own youth organizing and/or experience working in an undocumented student support center. We are guided by the following questions: (1) How do New Jersey immigrant organizers make meaning of and create spaces of hope and home through their organizing? (2) What propels this work and sustains it across cohorts of organizers? We discuss five general areas in response: the experience of invisibility and organizing efforts that aim to counter it, the co-construction of homespaces within higher education institutions, the importance of (re)setting narratives, celebrating wins while pressing for more, and the intergenerational work that inspires and sustains change. We close the article with reflections on the ways in which formal and everyday organizing are acts of love and care, from which home is collectively built.
\end{abstract}

Keywords: undocumented youth; organizing; access to higher education; immigrant support centers

\section{Introduction}

A popular meme across social media sites shows "How it started ... How it's going" with images illustrating change, growth, consistency, or even stagnation over time. In the images below (Figure 1), we highlight moments in New Jersey's fight for undocumented students to have better access to higher education. First, with tuition equity in public universities, then, five years and another administration later, state financial aid and two years after that, access to occupational licenses. The consistency over time centers on youth immigrants and their, to use abolitionist terminology, co-conspirators [1] as they organize, struggle, and push for change. Chronicling these stories is part of an ongoing project undertaken by a collective of undergraduate students and faculty working with The Center for Undocumented Students (TCUS), a university-based center whose mission is to support its undocumented, precariously authorized and mixed status family student community. The authors of this piece are members of one of the research groups, creating a narrative archive of organizing around New Jersey's "Dream Act" legislation [2]. Our research group currently is made up of members who are directly impacted by the change or who were/are involved in some aspect of the change-making. Coming from a participatory standpoint, we are enacting an approach where the people developing the questions, asking them, and sharing the narratives are also from communities who are impacted [3]. In this way, we are creating knowledge together, and our different positionalities within the collective offer different modes and avenues of bringing/giving the stories back to communities [4]. 


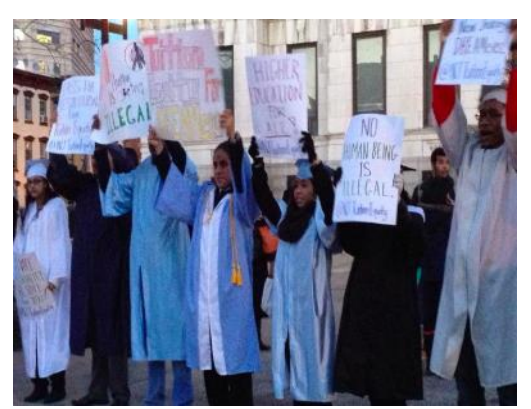

How it started 2013

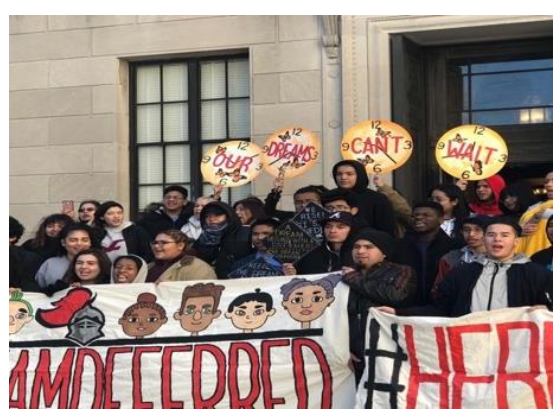

... How it's going ...

2018

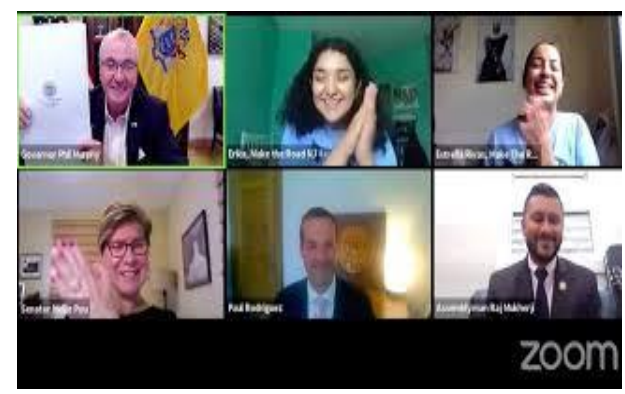

... and going ...

2020

Figure 1. NJ organizing 2013-2020; Photo credit Anakbayan New Jersey and Make the Road New Jersey.

We share some insights gleaned from the initial histories of the UndocuChronicles project, weaving them with first-person narratives from the co-authors through scholarly personal narrative [5] including reflections on TCUS as a site where we strive for centering migrant subjectivities. We write our conocimientos [6,7] in storied theory as college students, youth leaders/organizers, and a professor/director, navigating the between spaces of academy and community, searching for and creating home(s). As such, our writing shifts between I/we/they voices and perspectives, where we reflect on experiences through prisms of complexity. This means that we question narrative binaries of only damage or desire, resistance or subjugation, hope or despair, and acknowledge that a both/and stance can occur in alternating cycles or concurrent cascades (see also articles in this special issue).

In this piece, we create a dialogue between participants, each other, and the broader literature to sift, lift, and thread through youth/young adult immigrant subjectivities. We are guided by the following questions: (1) How do New Jersey immigrant organizers make meaning of and create spaces of hope and home through their organizing? (2) What propels this work and sustains it across cohorts of organizers? We structure our conocimientos from this dialogue into five areas: the experience of invisibility and organizing efforts that aim to counter it, the co-construction of homespaces within higher education institutions, the importance of (re)setting narratives, celebrating wins while pressing for more, and the intergenerational work that inspires and sustains change. We note that these narratives are situated in the context of New Jersey organizing, an area not often centered in this literature, or construed as simply an auxiliary of New York [8]. Considering the conditions under which this change work happens, we discuss the interplay between layers of institutional, state, and national organizing. We also look across cohorts of immigrant organizers for multidirectional influences of hope, inspiration, and critical knowledge as forms of what Yosso terms community cultural wealth $[9,10]$. In the next section, we discuss how structural invisibility propelled a counter-movement, or counter-spectacle [11], where fighting to be seen represented one step in a journey of belonging and creating home. 


\section{Countering Invisibility}

What does invisibility look and feel like in undocumented communities? Based on some of the authors' personal experiences and the testimonies of people around us, we offer the following snapshot:

Undocumented immigrants are often taught to make themselves invisible, so much so that the official count of undocumented people in the United States is estimated to be between 11 and 22 million [12]. Undocumented children are often taught, purposefully or by observation, to hide themselves too $[13,14]$. Some hide by accident, their status hidden until the day they ask their mother for a social security number to fill out college applications. Others are taught on the day Immigration and Customs Enforcement (ICE) knocks on their neighbor's door and their babysitter tells them to hide behind the dresser. Growing up remembering nothing but the sound of shushing, prayers, and knocking filling the room, in a moment realizing they would never feel safe again. Their father was there one moment, the next he was gone. Some are told they were born in a local hospital but are confused, because if that were true, why do they remember abuelita and hold memories of a faraway campo? Why did they leave and how can they come back? There comes a time where undocumented students wonder what this missing piece of paper has to do with their ability to live peacefully [15]. When this day comes, it is followed by the question "am I the only one?" Students sitting in their classrooms, can wonder daily whether anyone else holds this same fear. Regardless of how many people in their city look like them or struggle with English the way their parents do, there is an assumption that undocumented students are alone in carrying this weight in their chest.

One of the organizers of the NJ tuition equity campaign, " $\mathrm{C}$ ", shared this kind of experience of invisibility in the DACA before-times. Deferred Action for Childhood Arrivals (DACA) refers to an executive action in 2012 that granted undocumented young people who migrated to the U.S. as children and met specific criteria limited protection from deportation, work authorization for two years at a time, and other benefits. The partially inclusive and temporary nature of DACA facilitated the subsequent administration's continued efforts to dismantle this protection as part of their broader anti-immigrant agenda. Despite this, with court challenges, sustained organizing and shifting immigration priorities, as of May, 2021, DACA remains in effect. Being DACAmented positioned certain groups of undocumented youth in a partially included liminal or "abject" status but with new modes of agency and resistance [16]. Part of these new modes of agency and resistance took the form of countering invisibility, as $C$ discusses below. In a climate of fear of disclosure before DACA, C wondered if she was the only one in her community who was undocumented.

Before DACA or even before the Dream Act fight, no one would say they were undocumented. There was so much shame and fear about being vocal about it. And so like, I am from [a city] that is mostly immigrants. Like when you go to school and everyone is speaking Spanish. But no one would say they were undocumented, and I tell people this story that like when I went to school I thought I was the only person that was undocumented. Which is not true, because if you know [the city's] demographics you know that that could not be possible first of all, but that was because you would not talk about it. You just wouldn't talk about it. But after 2010, 2012, there was more of that, like almost the whole political climate changed and all of a sudden people were empowered and coming out and also saying, which is also why we had all these coming out actions right, and people were coming out and feeling empowered and claiming their undocumented status.

What $\mathrm{C}$ narrates above aligns with a tenet of Aguilar's UndocuCrit framework. Aguilar [17] argues that "fear is endemic among immigrant communities" (p. 3) because of state surveillance and policies rooted in racial capitalism and white supremacy. When in a state of precarity where conditions of fear are created intentionally, people can respond with strategies of protection, to hide and push back in turns. Thus, the experience of invisibility can manifest as internal and external processes [18]. It is a survival strategy that families adopt and in turn impart for the sake of safety in a potentially hostile environment, 
and a structural condition that creates this need. Structural invisibility [19] is apparent, for instance, when lawmakers publicly hail the worth of essential workers during the COVID-19 pandemic, yet routinely deny basic protections or material support for the largely undocumented immigrant members who make up this workforce [20], unseen or silenced in terms of allocation of resources [14] but made visible most egregiously through discourses of criminality [11,21], exemplified by such measures as the implementation of the VOICE hotline (Victims of Immigration Crime Engagement) by the administration in 2017, or more subtly through ongoing performative inclusivity.

As pointed out in $C^{\prime}$ s quote, earlier immigrant youth organizing centered on increasing visibility in public spaces, with discourses and actions related to "coming out of the shadows", with slogans like the national immigrant youth organization United We Dream's "undocumented and unafraid" [22,23]. With visibility came danger, yes, as evidenced by immigrants speaking out at rallies who were later detained by ICE. However, as many youth organizers we work with pointed out, even following all the shadow rules, heads down, not speaking out, and not seeking potential support, people still get deported [24]. Challenging this type of invisibility can create a layer of community protection born of awareness and action, through connections to networks of support [18]. It can be soul nourishment as well, because with visibility comes the agency of claiming an undocuidentity and the power in knowing one is not alone [23,25]. It creates a base of mutual aid and builds power for movement-making, opening a space for home [22,26].

\section{Creating Home(s) within Institutions}

In the previous section, we described how structural invisibility operates as a way to dismember communities, in part so that they do not find support in each other [27]. We also discussed the work involved in countering this to make themselves seen. The context focused on early organizing efforts, occurring at a local level but part of a national movement, specifically with "coming out" actions, which inspired a sense of belonging to a proud undocuidentity. Shifting from broader organizing efforts to hyper-local ones, in this section, we reflect on creating home spaces within institutions, specifically, in a college environment.

The creation of a physical space, a home, is important to the healing of students who have not been permitted to have their own without fear $[10,28]$. There is a need for spaces where students who grew up watching elected officials dehumanize them in front of the entire country write on poster signs "Power to the People, No Person is Illegal"; where students, taught to keep their legal status a secret, hear the phrase "no papers, no fear" for the first time; where students who had grown up believing they were the only ones with this secret lodged in their throats sit in a circle sharing with each other what it felt like to have lost a home the first time they realized they were not welcomed here; and where there is a sense of belonging and shared ownership, at the very least, because these are the types of spaces they have fought for.

At TCUS, students continue to co-create such a space, informally yet intentionally called la casita, as a response to the "am I the only one" question, as another home. Part of an existing Social Justice House, TCUS emerged first as a physical space in 2014, with couches, an office area, a kitchen with a modest food pantry, a whiteboard, and tables. The walls are adorned with immigrant rights campaign artwork, pictures, and posters. Led by Dr. Brown, the house operates as a community space where student clubs and outside community organizations gather, plan, and organize, with a backyard, garden, and mural painted by students. As such, the intention is also for the space to be one of celebration and joy [29]. We have our healing circles and gatherings, equipped with donuts, empanadas, pizza, or pupusas, in the spiritual and cultural tradition of hospitality. Students are invited for specific gatherings or to complete homework with their friends who work there. If an extra plate, sanitary napkin, coat, or can of beans or pasta is needed, students can pick something up from our closet or food pantry, more recent additions to the space. The center is run almost entirely based on donations from community members and church/religious groups. In pandemic times, one of the things we 
miss most is the comfort of this physical space. For some students (and faculty), this is one of the few spaces they feel free on the campus.

Over time, TCUS expanded from being a symbol of the university taking a public stance on supporting undocumented students, to a physical space of (relative) safety and belonging, including targeted supports and services. These took the form of community know-your-rights sessions; workshops on internships, careers, and family; legal and wellness supports; book vouchers and modest tuition assistance for juniors and seniors; and connections to organizing and advocacy work with community partners. Most recently, TCUS has been expanding to include research opportunities about, with, and for immigrant youth. Immigrant youth leaders are an integral part of the TCUS team, and through work-study or internships, continue to shape the direction(s) of the center. These offerings are quite modest in comparison to other university-based centers and offices and have only been made possible through partnerships with others, particularly non-profit and immigrant rights organizations.

As alluded to earlier, such spaces are not given, but often fought for, as with other protections, rights, and services within institutions, local municipalities, or national policy. When it comes to undocumented students navigating pathways to higher education, it is often immigrant youth who lead the way for one another, sharing what Yosso [9] calls navigational capital in her community cultural wealth model. The work undocumented students do to gain access to resources from the university is often forgotten when the institution gets acknowledged for providing these resources, often framed as "gifts" from the university to the students. It is not a gift when students had to fight for it.

This is also the case for TCUS. The center did not simply appear one day out of the kindness, vision, or leadership of a single person, but could be traced back to waves of student organizing. On-campus actions around the Dream Act in the early 2000s, not easily welcomed at first by the college administration, raised awareness about undocumented students, at this time understood as "Dreamers" who were brought here by their families through no fault of their own [30], having the right to belong in higher education. This helped frame the discourse, concientizando students, staff, and faculty: students started disclosing their status individually to professors and/or staff, who then connected to one another to find avenues of support. From there emerged an underground network, where staff, faculty, and students would seek out trusted sources and communicate with each other what was learned, usually to leverage resources to support a particular student issue [31]. What was underground became more visible, collective, and proactive over time, particularly after DACA was implemented. A formal proposal for a center was created and ultimately accepted, and the university's center for undocumented students celebrated its opening in 2014 [29].

\section{4. (Re)Setting Narratives}

In the TCUS origin story described above, we shared the bends and turns of a winding pathway toward the creation of a local homespace. Zooming out from a local to a broader contextual view, we examine next the importance of narratives and discourses around who are the change-makers, as another way in which homespaces are constructed or denied. Jennifer (second author), the current director of TCUS who has been at the university as an administrator and professor for close to 20 years discusses:

I often get asked "how did you do it" or get applauded for the work that I, representing the center, do here. As a Latina with citizen privilege, I find the "credit" I get for this to be uncomfortable. In part this is because I feel there is always so much more that can be done, but also, asking what "I" did, ignores the labor youth and other community members have and continue to engage in to make this work possible. I certainly did not "create" TCUS. It was forged over time, through struggles that started with students who built the foundations, even though they did not personally benefit since the center was instituted years after they graduated. It was created and is sustained in community with other faculty, 
staff, and current students, with a strong TCUS alumni base who return for gatherings to connect with current students and re-engage one another.

This speaks in part to the importance of who creates narratives, who hears them, applies them, or shifts them, and when there is an accomplishment or "win" (or win-alongthe-way), who/what is credited and who is excluded. The work of creating narratives is particularly evident in the political sphere, as dominant discourses around immigration are used to justify immigrant dehumanization. As other scholars have noted, defining immigrant experiences in terms of, for instance, criminalization (for e.g., "gang" membership and violence), labor ("they are taking our jobs", or not paying taxes), legality (they are breaking the rules, illegal = not a person), and meritocracy (Dreamers and the good vs. bad immigrant) can have material and policy consequences [21,32]. Even framings such as "President Obama gave us DACA" erases the work of thousands of undocumented organizers, many of them people of color, who risked their own safety for the protection of their communities. For this reason, it is important to highlight the movements behind the wins, because whether they are attributed to singular charismatic leaders or as the specific accomplishments of a politician, excluding the labor of communities from these discourses can lead to simplistic understandings of how change can occur and diminishes the power and community cultural wealth of those most impacted.

In the past twenty years, community organizers have succeeded in winning in-state tuition rates in eighteen states [33]. Organizers have gone back and taken their win one step further, with victories granting undocumented students need-based state financial aid in at least six states. However, in states classified as restrictive, like Georgia and Alabama, undocumented students are prohibited from even enrolling in public institutions. This has not, however, occurred without strong resistance. In Atlanta, Freedom University offers undocumented people free college level classes, college process assistance, and a safe space for learning [34]. This illustrates how even in the most restrictive places, people have found a way to thrive and to "jiggle open" closed doors. One local NJ organizer who was part of the fight for earlier versions of the Dream Act put it this way:

No matter how many times people tell you you can't do something, you can't know until you try. So you can't shut that door. At least try to open it. At least jiggle that door, at least wiggle it, in order to see if it's really closed for you. And then try the next one.

This quote exemplifies what some have termed the endurance labor of immigrant youth organizers, who are haciendo puentes al andar [35] with their feet, hearts, strength, and fears, creating the footpaths for their communities to walk. It is important that these stories of possibility within constraint be part of a larger more nuanced narrative of change within communities. Shifting narratives so that they reflect the oppressive structures that harm immigrant communities, the agency and power the same communities can have, and the joy and pain potentials outside these framings legitimates their complexity and personhood [17]. Communities seeing their own stories and re-setting their own narratives is a powerful way to claim space and belonging as " $\mathrm{L}$ " argues later in this paper.

\section{Celebrating Wins While Pushing for More}

Organizing is creating, building, sharing, and forging the spaces, opportunities, and conditions for change to occur. Sometimes this is built across layers of change, with one cohort taking on the next step of the struggle started by predecessors; sometimes it is fighting to reclaim ground lost or taken. The trajectory of New Jersey's fight for access to higher education can be described in this way. It occurred in layers, or waves of action over a period of years, amidst different local and national climates. Sustaining the movement meant celebrating gains, or wins, while pressing for more. As a DACAmented youth organizer, Maria (the first author) has often told this story as part of her organizing with Make the Road NJ, with politicians, at rallies, in op-eds [36] in workshops at schools, and more recently in academic conferences and writings. A version of this narrative is written below [see also 2]: 
In 2012, President Obama announced the DACA, which was the result of fierce organizing by immigrant communities. The program allowed for young undocumented immigrants, who met certain qualifications, access to work authorization and a social security. This allowed DACA recipients to work, drive, and travel. An estimated 800,000 people were able to benefit from this program. They could work. They could drive (at least in our state). Why weren't they given access to an affordable college education? This led to the NJ financial aid fight of 2013. With their caps and gowns and compelling stories, undocumented youth went to state legislative hearings and took to the streets. And they won! The governor at the time, Chris Christie, signed the Tuition Equity Act also known as the New Jersey Dream Act, making undocumented students in New Jersey eligible for in-state tuition. It was a significant step in the fight of undocumented students towards an accessible college education. However, Christie vetoed the part of the bill that made it possible for undocumented students to get state financial aid. For undocumented students, the fight did not end. At the national level, in 2017, with the Trump administration, DACA was rescinded. But before and after the rescinding of DACA, immigrant youth leaders committed themselves to months of resistance. We realized that, while on a state level, federal immigration policies could not be fixed, we could fight to expand access to state resources for undocumented families. We knew what we wanted: to make New Jersey the tenth state in the country to grant undocumented immigrants access to state financial aid. And in 2017, history repeated itself. Organizations worked with undocumented students to testify before assemblies about why the bill was necessary. We filled the state courts during hearings and votes to ensure that our representatives were seeing us there. To raise awareness among the public, we took part in protests outside of the offices of representatives and city halls to gain support for the bill. We filled the streets with our demands. The whole fight was based in community. If they cried, they cried together. If there was a setback, they came up with a solution together. If they won, they won together. And in 2018, Governor Murphy signed the second part of the New Jersey Dream Act, making NJ undocumented students, who met certain requirements, eligible for state aid and programs like the Educational Opportunity Fund, which was denied us in the past.

At each point, there was a celebration of the win, with a simultaneous push to keep fighting. Sometimes these fights were to push for the next step, and at other moments the struggles surrounded implementation and ensuring that politicians and institutions charged with making changes actually made them. The framing of these changes as "wins" in this context can be strategic; within communities, it is important to allow time and space for celebration, amplifying the sense of agency and possibility necessary to sustain the work of change. However, there are always caveats, calls to continue the work, because wins can connote an end to struggle, a completion of sorts, an implication that the barriers and larger oppressive systems they are symptomatic of are no longer in place. There is a balance to the narratives organizers use because, in the absence of large-scale systemic change, there is always more that needs to be done. Each "small win" accomplished can be precariously held, particularly for the incremental type of change impacting vulnerable communities, usually of color. For the 2013 tuition equity win, the subsequent work centered on pushing for state financial aid, the critical piece vetoed during final passage of the act. The 2018 financial aid expansion had initial difficulties in implementation, including communicating its existence to impacted students and schools. The extension of this fight was in addressing opportunities for undocumented youth who sought jobs related to their degrees once they graduated. In 2020, through pandemic-modified organizing, New Jersey passed a bill expanding access to occupational licenses for state residents who qualified regardless of immigration status. Each state policy success built on the next, with the work of sustained organizing led by different cohorts of immigrant youth, long-time organizers, and adult co-conspirators who continued the struggle.

When the different phases of the NJ Dream Act passed in 2013 and 2018, though only five years apart, they did so under different local and national contexts. Significant DACA decisions surrounded both of these campaigns. In the 2012 fight for tuition equity, they 
organized under a Democratic President, Obama, and a Republican New Jersey Governor, Christie. Immigrant activists ran on the hope left over from the announcement of DACA such that, suddenly, even under a Republican Governor who had openly commented against the bill, anything was possible with enough push. In the 2018 fight for state financial aid, undocumented organizers acted on the urgency caused by the Trump administration's constant attacks against the immigrant community, amidst the backdrop of a supportive Democratic governor. While the national picture looked increasingly bleak, the press for change locally became more critical and possible. It is important to note, however, that this is not to suggest clean lines of welcome for immigrants between the two major political parties in the U.S. Over the years, both have been responsible for the detention, deportation, and separation of families and creating oppressive immigration policies. In recent history, we see examples of this from Bill Clinton's 1996 "Illegal Immigration Reform and Immigrant Responsibility Act" to Trump's reign of terror on immigrants, which built on and exploited structures created by his predecessors to implement a platform of ethnic expulsion. The underlying policy issues across administrations are rooted in white supremacy, heteropatriarchy, and racial capitalism, and the work of dismantling these structures involves work across generations of struggle.

\section{Intergenerational Work That Inspires and Sustains Change}

In this previous section, we see an interplay of influences between local and national contexts for organizing, and narratives of celebration and wins, with further work attached. In further reflecting on what sustains this work, what compels and nourishes it, we consider generations of youth immigrants who organize for change and how they draw strength and power from each other. It can begin with moves from personal to collective power, as $C$ explains:

When I became involved in activism or organizing it was very much out of self-interest. I was undocumented, I was trying to go to school, and I was just trying to figure out a way. So it very much started out of self-interest, but I think that throughout it, that changed, you know, the personal transformation. I think you start seeing, especially when you start organizing with other people, you start to see that it's not just you, and so, yeah, you start seeing your interest as a part of a larger community but with that also comes ... you also carry the fears and responsibilities of that entire community, which is really real.

Over the years we have heard undocumented organizers respond to comments they often receive about how brave and resilient they are for taking part in these actions. Part of the response is that they organize to live, that it is more survival than choice, because the consequences impact them so profoundly. In organizing to live, the sentiment can be "if we do not take action, who will? So we must". As described earlier, this forges community, and in so doing carries power, but with it also the weight of fear, hope, and despair, as was articulated in the previous testimony. When belief in community power is tested, by retaliation through immigration enforcement, public disparagement of immigrant families, threats, and intimidation, or even just seeing that their efforts do not result in the change they hoped for, this "holding" responsibility can feel crushing. The other part of the response is that they would not need to be so resilient and brave, holding so much, if white supremacist, xenophobic, racial-capitalist structures did not force it on them.

In describing her organizing both at the state level with MTRNJ for financial aid and occupational licenses and at her campus for the right to attend a career fair without the presence of Customs and Border Protection, Maria identifies what compelled her to organize. Its foundation lay in questioning the underlying "law of gratitude" expected of immigrants: that they should be grateful for whatever meager societal offerings they may get and not question them or expect more [37].

As our federal government leaves undocumented communities stranded during the COVID-19 pandemic-and continues to do so by refusing to include them in any stimulus relief package, it is difficult to remain unaware of the clear abuse that exists in our society. When I saw, through this experience, just how we, the immigrant community, are willing 
to accept less than we deserve, I think of the labor this country extracts from us. The root of my organizing as a high school student was pushed by the question, "are we not tired of getting bones thrown at us and expected to be grateful, as if we are not the ones putting food on American tables?" We are tired of bones. Similarly, it is not enough for universities to accept undocumented students. What are they doing to support us? What are they doing to empower us? What are they doing to ensure that students who are really safe nowhere at the very least feel safe there? I wonder how complicated it must be to understand us when this is not your story. Those scarred and burned hands are not your hands. Those children in cages do not look like your children. You know you will eventually get your federal relief check; undocumented families know we will never see ours. However, you are able to stand in a church, on a stage, on a podium we have paid for, with the labor of our bodies and minds, and say that we have the same values. In conversations, we can sometimes sound the same and think we are looking for the same things. However, when it comes to action, sometimes it is as if we never even tried to understand each other.

Like Moulin's [37] analysis of the freedom-protection exchange implicitly expected of refugees, in questioning the gratitude logics "are we not tired of bones", Maria connects the ways in which "gratitude reflects social hierarchies and places the one who receives into a subordinate position, where they are expected to obey the rules, natural or civil, as a form of reciprocity" (p. 62). Critique or protest in this framework can then be read as ingratitude, further positioning immigrants "as undeserving, unwelcomed others who are not entitled to climb the steps toward properly authorised citizenship status" (p. 63), which reinforces policies of exclusion already operating for undocumented communities.

Highlighted perhaps most strongly in recent history during the Trump administration's zero tolerance policy, images of families being separated by armed, uniformed men, with Brown children in cages calling out for help, led to an international outcry. However, still many looked dismissively at these images, and the policies that lead to them. Making this sentiment most clear, the then first lady wore the message "I really don't care" on her clothing when visiting a detention center. As Maria explained earlier, perhaps it is because "those scarred and burned hands are not your hands ... those children in cages don't look like your children" and are therefore not granted the same humanity. These are the more dramatic cases, where white supremacy was just made more explicit, uplifted, and celebrated, while revealing that this was the underlying ideology behind the policies all along. There is an expectation that the harshest fights can come from the more extreme corners. While there is truth in that, it is sometimes the more subtle expressions that can cause fissures of doubt, through tepid support or internal tension on the "right" way to fight.

In the tuition equity campaign, organizers discussed how they struggled against not only a governor who was publicly hostile towards the bill but also other groups who felt that it was unwinnable, and therefore, not worth fighting. As one organizer, "L," recalls:

We led a fight against Governor Chris Christie, who at the time had voiced that he would not help undocumented people in any way. And so when we began the campaign, it was kind of like a straight uphill battle within the organizations that claimed to support the undocumented community as well, because they were like, why are you wasting your time? This man [the governor], he's not gonna support you. And in the past, like we've seen him, keep to that [stance]. So I think, to that extent, it was kind of hard to build strength among our own organizations who for a while have been supporting immigrant rights. The fight for tuition equity was really pushed by a whole bunch of people who had never done this before. People who were kind of just fed up with the fact that nobody was helping us and the people who were upset, they helped us learn about this fight. And so that, I think, was the spark that New Jersey needed at the time ... We knew that the odds were against us; the only thing that we could potentially win [with] was the people's narratives ... and we didn't really understand how powerful that could be because that was really what carried our campaign.

In this narrative, there was a discussion of the clashes between theories of change among organizers [38]. Do you only take on fights that are "winnable"? How is this 
determined and by whom? Being "tired of crumbs", being "fed up with the status quo", can be the impetus or spark that lights action and compels change. Focusing efforts determined collectively is another strategy. However, in either case, it is important to ask from what wells of hope do immigrant youth draw to sustain their work for change? In the stories told by past and present youth organizers, we see intergenerational exchange and a carrying of hopes and fears from one cohort to the next as struggles continue with different contours. Initial organizing from the 2000s framed a Dreamer narrative that carried on through DACA and, more locally, versions of NJ's recent legislation [30]. However, a lesson learned from the early organizing was that this was not the approach to use moving forward. The Dreamer narrative was critiqued, as youth organizers saw how it allowed others to frame their families in discourses of blame and deservingness [30,39]. This learning was passed on to current cohorts of youth organizers, who speak more explicitly about organizing for the 11 million, for themselves and their families, and rejecting the good versus bad immigrant assumption underlying the Dreamer frame. As L reminds us, when fighting an uphill battle, with politicians who let you down, there is power in setting the narrative with, for, and by the impacted people.

Moments where youth organizers come face to face with the activists that laid the foundation for much of their work are undeniably powerful. It is aspirational capital [9] that passes between cohorts and generations of organizers and the communities of which they are part. Maria's reflection affirms:

Using each other and the work made possible by our own mentor's patience and persistence as sources of hope allows us to imagine a world in which we are not victims but change makers. When policies are passed, you don't just see them as something benefitting you, you also learn to value the changes it will make in your community. A community that has to care for each other. Organizing begins to feel less like only a political action, but also an action of revolutionary love and care [40].

\section{Hopeful Pero No Confiada: Concluding Thoughts}

We conclude this piece reflecting on what we have learned in these dialogues about more formal community organizing and connecting it to the everyday organizing seen in community life, most recently during these pandemic times. We braid the strands we introduced in this article on the role of in/visibility, resetting narratives, celebrating wins while pressing for more meaningful change, and organizing intergenerationally or across cohorts of organizers. These braided strands can form knots that are messy but life-giving in their strength, both inspiring and sustaining the work of change over time [41]. Below, we highlight what we have learned in a series of affirmations about, with, and for undocumented communities.

\subsection{You Are the Resource Your Community Needs}

Part of growing up undocumented is knowing you, no matter who you are, are a resource to your community. It is important that we recognize our community's cultural wealth [9]. As immigrant children, the roles we have fulfilled were many: translator, assistant, babysitter, tech support, and more. All of this, though, rarely feels out of line, because you come to understand that in communities like these, each other is all you have. This is particularly salient now, as the COVID-19 pandemic spreads throughout the world and the U.S. government leaves undocumented people stranded no matter how "essential" their labor. More than ever, it has been cemented in our community that when circumstances are the most difficult, we are our main source of support and aid [42].

As undocumented people are afraid of reaching out for medical support due to fear of being reported to immigration enforcement, many depended on neighbors and community organizations to drop off medicinal recipes, buy groceries, and provide emotional support. For example, as the pandemic spread through my (Maria's) heavily immigrant neighborhood, I have seen cans or small boxes with the names and faces of those who did not survive the virus, which now line almost every local bakery, laundromat, and grocery 
store counter. On the surface of these boxes and cans, along with the names and faces, is a small biography of the deceased loved one, almost always written in Spanish, and at the top is a small opening for anyone passing by to insert money. At the end of the week, the families of those loved ones walk throughout the city, collecting their cans, hoping that they have enough for funeral expenses, which often includes the cost for the body to return to the country of origin. Families also know that if these biographies specify that the loved one was from a different country, more donations would be offered, because of the shared experience of being far from their home of origin, fearing never being able to return. When community members see the faces on those cans of people who like themselves left one home behind, they are moved to do something to help them get back.

This is not to suggest that with such mutual aid efforts, institutions and the state are absolved of the responsibility to support all its members, including those who are undocumented [26]. Quite the opposite. However, as stated earlier, the sentiment shared by many undocumented organizers is "if we do not take action, who will? So we must", and that same feeling is found in the communities these organizers come from. The necessity for mutual aid is felt in the lives of undocumented immigrants from the minute they become a part of the undocumented community. If I do not care, who will? If I do care, how can I not act?

\subsection{Organizing Is a Fighting Love That Creates Home}

Underlying all of this, then, is a framework of love, a bodymindspirit [43] concept we see in organizing and/as scholarship, whether as an armed love [44], a borderland ethic of love [24], or a revolutionary love [40]. Healing can be difficult while the wounds are still weeping, but in the face of continuing heartbreak in what Rios-Rojas [45] terms "pedagogies of the broken-hearted", the cross stitching of community care helps us keep moving, living, and loving.

We, as undocumented students, have been told that there are many locked doors for us and opportunities that we cannot benefit from because of our legal status. Yet, we have not let that stop us from wiggling and jiggling the door knob to see if by any chance the door will still open. This act of perseverance and hopefulness is what has allowed opportunities like financial aid and working permits to be available to many. While we have acquired major wins, there is still much left to be done.

Organizing is an act of resistance against the invisibility undocumented people are often forced into in order to survive. Organizing then itself becomes the new method of survival despite it bringing a visibility previously thought to be unsafe. The creation of a community that grows out of organizing becomes a home.

\subsection{We Are More Than Paperless People}

The narrative in the United States is to view undocumented people as, at its best, "paperless people" en route to becoming citizens. With this, the power of this group of millions of people is often diminished. In understanding the economic, political, and community power that is smothered under the threat of job loss, ICE raids ${ }^{1}$, and deportation, it becomes clearer how organizing can feel to many as a first gasp of fresh air, filling their lungs where the weight of their secret used to be. As argued earlier, it is important to reset this narrative by imagining our fullest selves and speaking our complexity.

Undocumented people are not simply laborers who willfully keep their eyes down and their hands working, they are also people who resist the conditions they are forced to live under. Undocumented people are also capable of joy and love so strong that many of them thrive under these conditions, using each other as a source of this strength. It must be noted

1 ICE raids in the U.S. refer to coordinated immigration enforcement actions, typically at employment or home sites, where undocumented immigrants are detained by agents to facilitate deportation. They are traumatic for families and intended to intimidate and instill fear in immigrant communities for the purpose of deterring future unauthorized immigration. For some history on the impact of immigration enforcement practices on children's mental health, see McLeigh JD. How Do Immigration and Customs Enforcement (ICE) Practices Affect the Mental Health of Children? American Journal of Orthopsychiatry. 2010; 80(1):96-100. 
that the risk that comes with becoming visible does not get lost in the minds of organizers and activists. Being "undocumented and unafraid" means understanding that the hope of what the community stands to win outweighs the fear of what we stand to lose [17]. "Undocumented and unafraid" is a green-light to the political and community power that is on the other side of the room xenophobia is keeping us locked out of [22]. Therefore, we remain hopeful, pero no confiada: not trusting of promises made by institutions and politicians, but hopeful that, in community, we continue creating home, here.

Author Contributions: The M.d.C.M. and J.A. contributed equally to all aspects of the article, from conceptualization, to the oral history research and all phases of writing. The K.R. author contributed to the collection of oral histories, analysis and final writing stages. All authors have read and agreed to the published version of the manuscript.

Funding: The oral histories referenced in this article received no funding.

Institutional Review Board Statement: The collection of oral histories for this project was approved by the Institutional Review Board of Saint Peter's University.

Informed Consent Statement: Written consent was obtained for the oral histories.

Data Availability Statement: Portions of the oral histories will be made available through a public archive.

Acknowledgments: We would like to express gratitude to Pyetra Camargo for her work when she was part of the TCUS research team. We would also like to give a special thanks to the organizers who have been directly or indirectly involved in this ongoing fight for undocumented students to obtain higher education. In 2013, the NJ Dream Act Coalition, Anakbayan NJ, Wind of the Spirit among others won access to the 2013 in-state-tuition. In 2018, organizations like Make the Road NJ, Cosecha, UndocuRutgers, American Friends Service Committee, and many more made it possible for the bill S-699 to be signed on 9th May 2018. While these organizers may never receive all the appreciation they deserve they will forever be in the hearts of the undocumented students that they have helped through their efforts.

Conflicts of Interest: The authors declare no conflict of interest.

\section{References}

1. Love, B.L. We Want to Do More Than Survive: Abolitionist Teaching and the Pursuit of Educational Freedom; Beacon Press: Boston, MA, USA, 2019.

2. Ayala, J.; Fine, M.; Mendez, M.; Juarez Mendoza, A.N.; Garcia Rivera, J.C.; Finesurrey, S.; Villeda, H.T.; Mena, V.; Azzam, K.; Galletta, A.; et al. ENCUENTROS: Decolonizing the Academy and Mobilizing for Justice. Qual. Inq. 2020. [CrossRef]

3. Torre, M.; Fine, M.; Stoudt, B.; Fox, M. Critical participatory action research as public science. In The Handbook of Qualitative Research in Psychology: Expanding Perspectives in Methodology and Design, 2nd ed.; Camic, P., Cooper, H., Eds.; American Psychological Association: Washington, DC, USA, 2012.

4. Torre, M.E.; Fine, M.; Alexander, N.; Billups, A.; Blanding, Y.; Genao, E.; Salah, T. Participatory action research in the contact zone. In Revolutionizing Education: Youth Participatory Action Research in Motion; Cammarota, J., Fine, M., Eds.; Routledge: New York, NY, USA, 2008; pp. 23-43.

5. Nash, R.J.; Viray, S. The Who, What, and Why of Scholarly Personal Narrative Writing. Counterpoints $2013,446,1-9$. Available online: https:/ / www.jstor.org/stable/42982209 (accessed on 1 January 2021).

6. Anzaldúa, G. Now let us shift ... the path of conocimiento ... inner work, public acts. In This Bridge We Call Home: Radical Visions for Transformation; Routledge: New York, NY, USA, 2002; p. 540.

7. Mayorga, E.; Rosales, A. Conocimiento, colectividad y curación: Understanding and addressing latinx youth mental health and wellness through PAR entremundos. Urban Rev. 2019, 51, 559-581. [CrossRef]

8. Lauria-Santiago, A.; Dalum Berg, U. Latino New Jersey: Histories, Communities and Politics; Rutgers University Press: New Brunswick, NJ, USA, 2021; manuscript in preparation.

9. Yosso, T.J. Whose culture has capital? A critical race theory discussion of community cultural wealth. Race Ethn. Educ. 2005, 8, 69-91. [CrossRef]

10. Person, D.; Keeton, R.G.; Medina, N.; Gonzalez, J.; Minero, L.P. Effectively Serving AB 540 and Undocumented Students at a Hispanic Serving Institution. J. Hisp. High. Educ. 2016, 16, 256-272. [CrossRef]

11. Negrón-Gonzales, G. Undocumented Youth Activism as Counter-Spectacle: Civil Disobedience and Testimonio in the Battle around Immigration Reform. Aztlan A J. Chicano Stud. 2015, 40, 87-112. 
12. Zarandi, M.F.; Feinstein, J.S.; Kaplan, E.H. Yale Study Finds Twice as Many Undocumented Immigrants as Previous Estimates. Yale Insights. 21 September 2018. Available online: https://insights.som.yale.edu/insights/yale-study-finds-twice-as-manyundocumented-immigrants-as-previous-estimates\#gref (accessed on 1 January 2021).

13. Suárez-Orozco, C.; Yoshikawa, H.; Teranishi, R.T.; Suarezorozco, M.M. Growing Up in the Shadows: The Developmental Implications of Unauthorized Status. Harv. Educ. Rev. 2011, 81, 438-473. [CrossRef]

14. Figueroa, A.M. Speech or Silence: Undocumented Students' Decisions to Disclose or Disguise Their Citizenship Status in School. Am. Educ. Res. J. 2017, 54, 485-523. [CrossRef]

15. González Ybarra, M. “Since when have people been illegal?": Latinx youth reflections in Nepantla. Lat. Stud. 2018, 16, 503-523. [CrossRef]

16. Ellis, B.D.; Gonzales, R.G.; Rendón García, S.A. The Power of Inclusion: Theorizing “Abjectivity” and Agency under DACA. Cultural Studies. Crit. Methodol. 2018, 19, 161-172. [CrossRef]

17. Aguilar, C. Undocumented Critical Theory. Cult. Stud. Crit. Methodol. 2018, 19, 152-160. [CrossRef]

18. Muñoz, S.M.; Vigil, D. Interrogating racist nativist microaggressions and campus climate: How undocumented and DACA college students experience institutional legal violence in Colorado. J. Divers. High. Educ. 2018, 11, 451-466. [CrossRef]

19. Lever, J.; Milbourne, P. The Structural Invisibility of Outsiders: The Role of Migrant Labour in the Meat-Processing Industry. Sociology 2016, 51, 306-322. [CrossRef] [PubMed]

20. Jawetz, T. Immigrants as Essential Workers during COVID-19, Testimony before the U.S. House Judiciary Subcommittee on Immigration and Citizenship. September 2020. Available online: https://www.americanprogress.org/issues/immigration/ reports/2020/09/28/490919/immigrants-essential-workers-covid-19/ (accessed on 2 April 2021).

21. Vega, I.I. Empathy, morality, and criminality: The legitimation narratives of U.S. Border Patrol agents. J. Ethn. Migr. Stud. 2018, 44, 2544-2561. [CrossRef]

22. Negrón-Gonzales, G. Undocumented, unafraid and unapologetic: Re-articulatory practices and migrant youth "illegality". Lat. Stud. 2014, 12, 259-278. [CrossRef]

23. Tafoya, J.R.; Michelson, M.R.; Chávez, M.; Monforti, J.L.L. I feel like I was born here: Social identity, political socialization, and deAmericanization. Lat. Stud. 2019, 17, 48-66. [CrossRef]

24. Chang, A. Privileged and Undocumented: Toward a Borderland Love Ethic. In The Struggles of Identity, Education, and Agency in the Lives of Undocumented Students; Palgrave Macmillan: Cham, Switzerland, 2017; Volume 9, pp. 27-46. [CrossRef]

25. Rodriguez, S. "People Hide, But I'm Here. I Count:" Examining Undocumented Youth Identity Formation in an Urban Community-School. Educ. Stud. 2017, 53, 468-491. [CrossRef]

26. Spade, D. Solidarity not charity: Mutual aid for mobilization and survival. Soc. Text 2020, 38, 131-151. [CrossRef]

27. Mayorga, E. Education in our Barrios, \#BarrioEdProj. In PAR Entremundos: A Pedagogy of the Américas; Ayala, J., Cammarota, J., Rivera, M., Rodriguez, L., Berta-Avila, M., Torre, M.E., Eds.; Peter Lang: New York, NY, USA, 2018.

28. Suárez-Orozco, C.; Katsiaficas, D.; Birchall, O.; Alcantar, C.M.; Hernandez, E.; Garcia, Y.; Michikyan, M.; Cerda, J.; Teranishi, R.T. Undocumented Undergraduates on College Campuses: Understanding Their Challenges and Assets and What It Takes to Make an Undocufriendly Campus. Harv. Educ. Rev. 2015, 85, 427-463. [CrossRef]

29. Brown, A.; Ayala, J. Creating undocu-joy: The Center for Undocumented Students at Saint Peter's University. In 2020 Yearbook of the Society of Jesus; JESUITS: Roma, Italy, 2020; pp. 137-140. Available online: https:/ /www.jesuits.global/documents_category/ yearbooks / (accessed on 2 April 2021).

30. Lauby, F. Abstract. Leaving the 'perfect dreamer' behind? Narratives and mobilization in immigration reform. Soc. Mov. Stud. 2016, 15, 374-387. [CrossRef]

31. Castillo, E.; Cutler, T.; Sepulveda, G. Work on the Ground/Underground: An Exploration of Latin@ Student Strategies and Supports in the Project of Higher Education. In Proceedings of the Presented at the Annual Eastern Sociological Society Conference, Baltimore, MD, USA, 18-21 February 2014.

32. Menjívar, C.; Gómez Cervantes, A.; Alvord, D. The expansion of "crimmigration," mass detention, and deportation. Sociol. Compass 2018, 12, 1. [CrossRef]

33. National Conference of State Legislators. Undocumented Student Tuition: Overview. 2019. Available online: https: / / www.ncsl.org/research/education/undocumented-student-tuition-overview.aspx\#: \{\}:text=Since\%202001\%2C\%2018\%2 0states $\%$ E2\%80\%94California,students $\% 20$ who\%20meet $\% 20$ specific $\% 20$ requirements (accessed on 2 January 2021).

34. Ashoka. Freedom University: Educating Undocumented Young People in Georgia. Forbes, 16 November 2017. Available online: https:/ / www.forbes.com/sites/ashoka/2017/11/16/freedom-university-educating-undocumented-young-people-ingeorgia/?sh=1a4e1b574c20 (accessed on 2 January 2021).

35. Anzaldúa, G. Borderlands la Frontera: The New Mestiza; Spinsters/Aunt Lute: San Francisco, CA, USA, 1987.

36. Mendez, M. Opinion: A new day for NJ's college-bound 'Dreamers'. Available online: https://www.northjersey.com/story/ opinion/contributors/2018/05/09/new-day-new-jersey-college-bound-dreamers/594501002/ (accessed on 1 January 2021).

37. Moulin, C. Ungrateful subjects? Refugee protests and the logic of gratitude. In Citizenship, Migrant Activism and the Politics of Movement; Nyers, P., Rygiel, K., Eds.; Routledge: Milton Park, UK, 2012. [CrossRef]

38. Tuck, E.; Yang, W. Youth Resistance Research and Theories of Change; Routledge: Milton Park, UK, 2013.

39. Patel, L. Deservingness: Challenging Coloniality in Education and Migration Scholarship. Assoc. Mex. Am. Educ. J. 2015, 9, 11-21.

40. Kaur, V. See No Stranger: A Memoir and Manifesto of Revolutionary Love; One World: New York, NY, USA, 2020. 
41. Delgado Bernal, D. La trenza de identidades: Weaving together my personal, professional, and communal identities. In Doing the Public Good: Latina/o Scholars Engage Civic Participation; González, K.P., Padilla, R.V., Eds.; Stylus: Sterling, VA, USA, 2008.

42. Ruth, A. Attaining the college dream: The effects of politics on the social capital of first-generation undocumented immigrant students. Hum. Organ. 2018, 77, 22-31. [CrossRef]

43. Lara, I. Healing Suenos for Academia. In This Bridge We Call Home: Radical Visions for Transformation; Anzaldua, G., Keating, A., Eds.; Routledge: New York, NY, USA, 2002; pp. 433-438.

44. Darder, A. Teaching as an Act of Love: In Memory of Paolo Freire. Speech Given at American Educational Research Association, USA, 1998. Available online: https: / files.eric.ed.gov/fulltext/ED426154.pdf (accessed on 2 April 2021).

45. Ríos-Rojas, A. "Pedagogies of the Broken-Hearted": Notes on a Pedagogy of Breakage, Women of Color Feminist Decolonial Movidas, and Armed Love in the Classroom/Academy. Front. J. Women Stud. 2020, 41, 161-178. [CrossRef] 